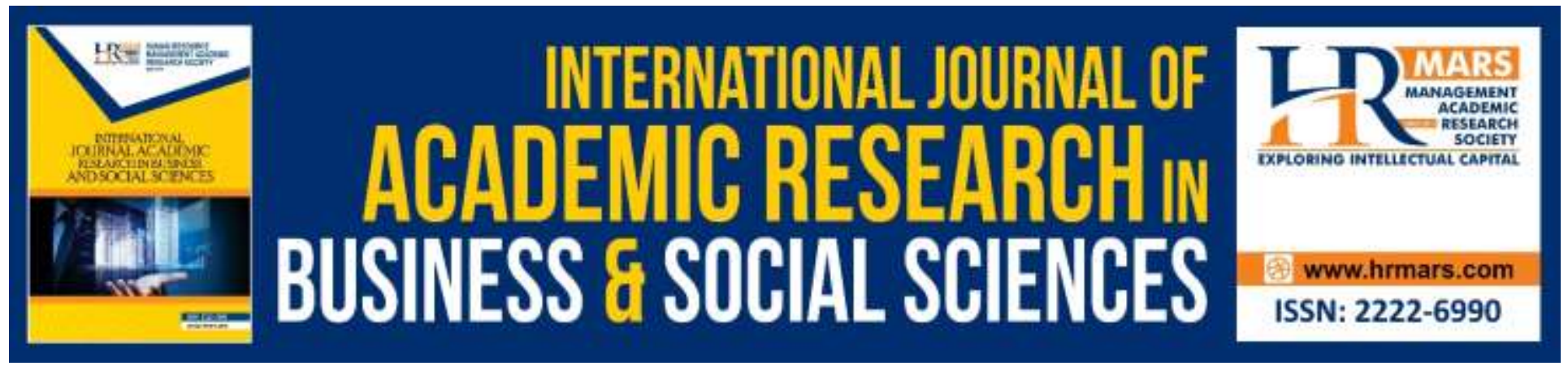

\title{
Macroeconomic Variables and Economic Growth: The Malaysian Perspectives
}

\author{
Mimi Syahirah Omar, Amirudin Mohd Nor
}

To Link this Article: http://dx.doi.org/10.6007/IJARBSS/v10-i3/7046

DOI:10.6007/IJARBSS/v10-i3/7046

Received: 05 February 2020, Revised: 24 February 2020, Accepted: 15 March 2020

Published Online: 28 March 2020

In-Text Citation: (Omar \& Nor, 2020)

To Cite this Article: Omar, M. S., \& Nor, A. M. (2020). Macroeconomic Variables and Economic Growth: The Malaysian Perspectives. International Journal of Academic Research in Business and Social Sciences, 10(3), 272-280.

Copyright: (C) 2020 The Author(s)

Published by Human Resource Management Academic Research Society (www.hrmars.com)

This article is published under the Creative Commons Attribution (CC BY 4.0) license. Anyone may reproduce, distribute, translate and create derivative works of this article (for both commercial and non-commercial purposes), subject to full attribution to the original publication and authors. The full terms of this license may be seen

at: http://creativecommons.org/licences/by/4.0/legalcode

\section{Vol. 10, No. 3, 2020, Pg. 272 - 280}

Full Terms \& Conditions of access and use can be found at http://hrmars.com/index.php/pages/detail/publication-ethics 


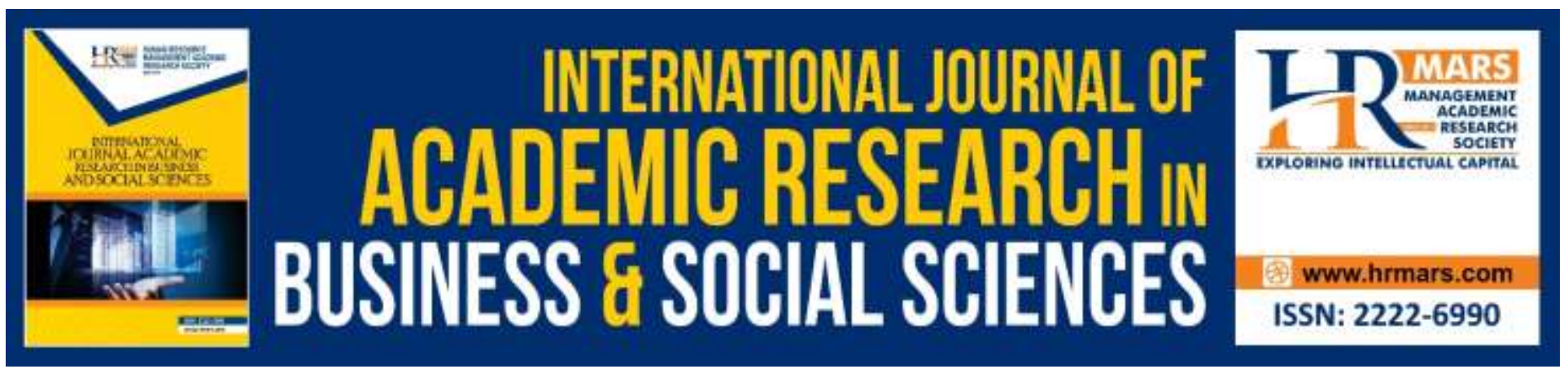

\title{
Macroeconomic Variables and Economic Growth: The Malaysian Perspectives
}

\author{
Mimi Syahirah Omar, Amirudin Mohd Nor \\ Faculty of Business and Management, Universiti Teknologi MARA, Melaka, Malaysia
}

\begin{abstract}
This manuscript examines the linkage between macroeconomic variables namely population, unemployment and export with the economic growth in Malaysia. This is owing to the conflicting findings produced by researchers in the past. Applying the multiple linear regressions (MLR) analysis for a time series quarterly data from 2006 until 2016, this study finds the presence of linear relationship between the respective variables. More specifically, population is significant and negatively related to economic growth, while export is significant in a negative manner. Contrary to our expectation, this study documented an insignificant relationship that unemployment has towards economic growth. This study is contributory to the policy maker and the academic community particularly for them to further understand the issues relating to the researched variables.
\end{abstract}

Keywords: Macroeconomic, Malaysia, Economic growth, Multiple Linear Regression, Correlation

\section{Introduction}

Economic growth continues to be one of the main agendas in most of the countries worldwide. Economic growth is an indicator of a healthy economy. Various strategies were formulated to stimulate and enhance economic growth. Malaysia, for instance through the National Economic Advisory Council (NEAC), had in 2010 introduced the New Economic Model (NEM), aiming to spur economic growth and to turn the country into a high-income developed country by 2020 . The objective is to bring economic prosperity to the nation in the long run.

Economic growth is very important to a country's future wellbeing. Huge spillover effect can be generated from a positive economic growth, may it be increased in consumption that would encourage private investment and increase in employment or a fall in unemployment for its citizen. The government, on the other hand benefit in terms of increase in tax revenue, and later contributes to the increase spending on public services. At the end, an increased in the national output would help reduced poverty and improve living standards given that households can afford to spend on more goods and services. 
INTERNATIONAL JOURNAL OF ACADEMIC RESEARCH IN BUSINESS AND SOCIAL SCIENCES Vol. 10, No. 3, March, 2020, E-ISSN: 2222-6990 @ 2020 HRMARS

Our motivation in pursuing this research lies on the fact that many researchers in the recent past have produced conflicting results on the economic growth and macroeconomic variables, be it the correlation or regression analysis. The literature on macroeconomic variables and economic growth revolving around the population, unemployment and export variables in various countries indicates an inconclusive finding that need further exploration. This study tends to carry the said task with the intention to find out the latest findings on their relationship, and simultaneously add to the existing literature on economic growth. Hence, the objective of this study is to analyze the selected macroeconomic factors namely population, unemployment and export and their impact to the Malaysian economic growth.

In the succeeding section, we highlight various literatures, followed by data description and methodology in deriving the estimation results. Then, the results are presented together with relevant discussions. Finally, we conclude the study together with future recommendations.

\section{Literature Review}

Economic Growth: In majority of the case, economic growth is measured by Gross Domestic Products (GDP). GDP shows a country's value of total productions on goods and services for a specific period. Therefore, increase in the GDP would increase the country's production, national income and expenditure. At the same time, the rise in economic growth alleviate the people's living standards and prosper in terms of increase consumption on goods and services.

Study on the effect of population towards economic growth: Previous studies seem to produce conflicting results. A positive relationship was found during the early years and after the year 2000 onwards (see Ozgur et al., (2009); Furuoka (2009) in Thailand; Obere et al (2013) in Kenya). Generally, population is the resource of labour. Increasing number of populations contribute to the performance of the economy because more people will be employed and subsequently helps to increase production and economic growth. On a similar note, some researchers in the past concur that rapid population growth will increase the level of performance in economic growth partly owing to savings and investments. Innovation and economies of scale is also the results of higher population (Meier and Rauch, 1995). Contradicting the above, negative relationship is also documented in the literature (Albatel (2005) in Saudi Arabia; Afzal (2009) in Pakistan; Abdullah et al (2015) in Bangladesh; Jorge et al (2017) in Mexico; Ahmed and Ahmad (2016) in Pakistan. Interestingly, most of the study concur that population increase has a direct positive linkage with unemployment which subsequently, reduces the economic growth. The above conflicting results suggest the inconclusive status of the relationship. Hence, the results can go either way.

Study on the effect of unemployment towards economic growth: Overall, the findings on the relationship between unemployment and economic growth is rather interesting over the years. Despite the majority negative relationship, the literature also highlighted the positive and insignificant status as well. Shorbaji (2009) states that most developed and developing countries faced problems with high rates of unemployment since unemployment increases poverty and reduces standards of living. Some studies applied the Okun's law framework and found negative relationship (Noor et al (2007) in Malaysia; Ang and Loganathan (2013) in developing countries). 
INTERNATIONAL JOURNAL OF ACADEMIC RESEARCH IN BUSINESS AND SOCIAL SCIENCES Vol. 10, No. 3, March, 2020, E-ISSN: 2222-6990 @ 2020 HRMARS

Similar results include that of the study of Alamro, and Al-dalaien (2014) in Jordan; Michael et al (2016) in Nigeria. Meanwhile, in contrast Ahmed and Ambreen (2014) discovered a positive effect of unemployment rate towards per capita real GDP in Pakistan, while no significant relationship is found by Mosikari (2013) in South Africa; Alhdiy et al (2015) in Egypt; Ibrahim and Mahmoud (2016) in MENA countries. The literatures remain inconclusive at the present moment. Nevertheless, based on the above discussions which gives weight to a more negative relationship, we expect the result to be more of a negative manner.

Study on the effect of export towards economic growth: Majority of the studies discovered a positive relationship between export and economic growth (Sentsho (2002) in Botswana; Tsen, W. H. (2007) in Middle East countries; Mudenda, Choga and Chigamba (2014) in South Africa; Hamed, Hadi and Hossein (2014) in developing countries; Ali et al (2017) in Pakistan). Export is one of the major sources of economic growth primarily in the long-term context. In contrast, Furuoka \& Munir (2010) posit a negative correlation status in Singapore. Hence, we expect the relationship between the two variables to be positive.

The foregoing literature on macroeconomic variables and economic growth revolving around the population, unemployment and export variables in various countries indicates an inconclusive finding that need further exploration. Hence, this study tends to carry the said task and add to the existing literature on economic growth.

\section{Data and Methodology}

The scope of the study is confined to the Malaysian quarterly dataset from 2006 to 2016. Data for the independent variables were gathered from Datastream. Meanwhile, data for the dependent variable was sourced from the World Bank Database. All data are logged to achieve stationary status.

Table 1: Summary of the Variables

\begin{tabular}{llllc}
\hline Variables & Abb & Proxy & Sources & Expected Sign \\
\hline $\begin{array}{l}\text { Dependent } \\
\begin{array}{l}\text { Economic Growth } \\
\text { Independent }\end{array}\end{array}$ & GDP & Gross Domestic Product & World Bank & \\
$\begin{array}{l}\text { Population } \\
\text { Unemployment }\end{array}$ & POPU & Population Rate & DataStream & $+/-$ \\
Export & UNEM & Unemployment Rate & DataStream & - \\
\hline
\end{tabular}

Our preliminary analysis to identify the trend of the variable using the scatter plot reveals a mixed relationship between the respective variables in Malaysia. As demonstrated in figure 1, the scatter plot shows a negative relationship between Population and GDP, no clear relationship between Unemployment and GDP and finally a positive relationship between Export and GDP. 
INTERNATIONAL JOURNAL OF ACADEMIC RESEARCH IN BUSINESS AND SOCIAL SCIENCES

Vol. 10, No. 3, March, 2020, E-ISSN: 2222-6990 ¿ 2020 HRMARS
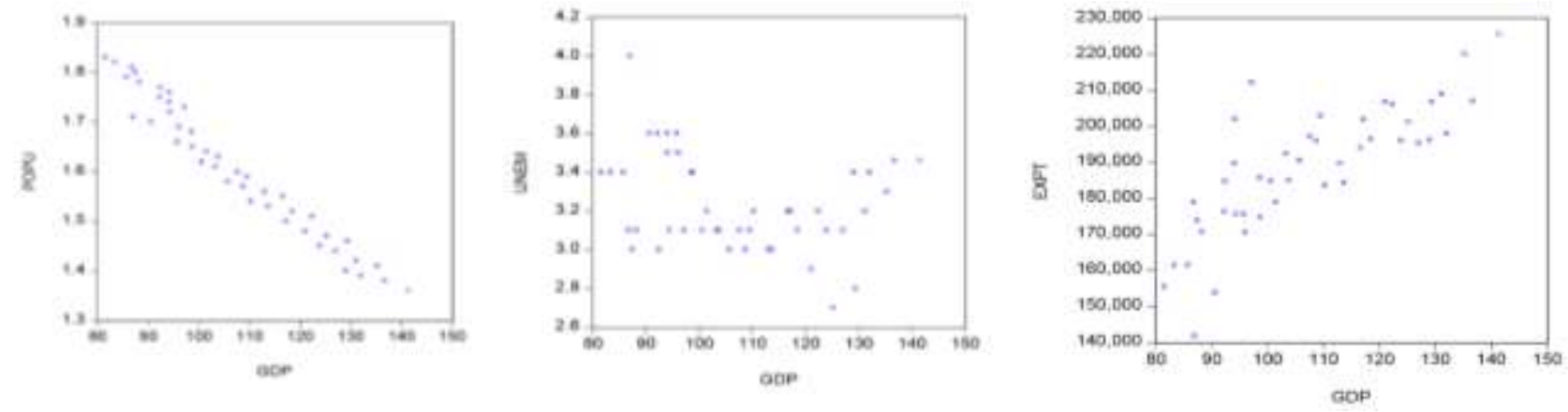

Figure 1: Scatter Plot for GDP, Population, Unemployment and Export Variables

\section{Regression Analysis: The Multiple Linear Regression (MLR)}

To answer the specified objective, we undertake the MLR. MLR is a linear regression model where only one dependent variable $(\mathrm{Y})$ and two or more independent variables $(\mathrm{X})$ are regressed to explain the effect of independent variables on the dependent variable (Gujarati \& Porter, 2009).

In line with the various literatures on economic growth and macroeconomic variables, we derived the following specification:

$$
G D P_{t}=B_{0}+B_{1} P O P U_{t}+B_{2} \mathrm{UNEM}_{t}+B_{3} \mathrm{EXPT}_{t}+\varepsilon_{t}
$$

The above equation shows that gross domestic product at time $t$ as a function of population, unemployment and export. GDP $P_{t}$ refers to Gross Domestic Product, $b_{0}$ refers to constant in the regression equation, $b_{1} P O P U_{t}$ refers to population, $b_{2} \mathrm{UNEM}_{t}$ refers to unemployment, $b_{3} \mathrm{EXPT}_{t}$ refers to export and $\varepsilon_{t}$ refers to error.

Population variable is a common variable included in the economic growth regression. Since results of the study is still inconclusive, we expect it can go either way, may it be positive or negative. As for the unemployment variable, we expect a significant negative relationship for this variable, while positive relationship is expected for the export variable.

To gauge the reliability of our estimation, we proceed to run several diagnostic tests related to MLR on these time series data. Those tests suggested that the model is adequately specified, and pass the relevant diagnostic tests as tabulated in Table 2 . The multicollinearity result also indicates the absence of multicollinearity problem as the correlations between the independent variables are less than 0.80 .

Table 2: Diagnostic checking for MLR

\begin{tabular}{lccccc}
\hline Test & $\begin{array}{c}\text { Residual } \\
\text { Mean }\end{array}$ & $\begin{array}{c}\text { Jarque- } \\
\text { Bera Test }\end{array}$ & $\begin{array}{c}\text { Durbin } \\
\text { Watson Test }\end{array}$ & $\begin{array}{c}\text { White } \\
\text { Test }\end{array}$ & $\begin{array}{c}\text { Ramsey's } \\
\text { RESET Test }\end{array}$ \\
\hline Coefficient Value/F-statistics & 0.0000 & 0.0897 & 1.8108 & 1.5125 & 0.3042 \\
P-values & & $(0.9561)$ & & $(0.1884)$ & $(0.5844)$ \\
\hline
\end{tabular}


INTERNATIONAL JOURNAL OF ACADEMIC RESEARCH IN BUSINESS AND SOCIAL SCIENCES

Vol. 10, No. 3, March, 2020, E-ISSN: 2222-6990 @ 2020 HRMARS

\section{Findings: Relationship Analysis}

Table 3: Estimated Coefficient of Empirical Model

\begin{tabular}{ccc}
\hline Coefficient & Coefficient Value & P Value \\
\hline$B_{0}$ & 1.6746 & $(0.002)^{* * *}$ \\
$B_{1} P O P U_{t}$ & -1.4830 & $(0.000)^{* * *}$ \\
$B_{2} U N E M$, & 0.0501 & $(0.1720)$ \\
$B_{3} E X P T_{t}$ & 0.3085 & $(0.0000)^{* * *}$ \\
$R^{2}$ & 0.9897 & - \\
F-statistic & 1289.97 & $(0.0000)^{* * *}$ \\
\hline
\end{tabular}

Note: The numbers in parentheses are P-values.

$*, * *$, and ${ }^{* * *}$ denote significance at $10 \%, 5 \%$ and $1 \%$ levels respectively.

The significant level at $1 \%$ by the F-statistic indicates that at least one of the independent variables used in the study has significant effect towards GDP in Malaysia. On the other hand, the Rsquared of 0.9897 signifies that $98.98 \%$ of variation in GDP in Malaysia is explained by the variation in Population, Unemployment and Export. The remaining $1.02 \%$ of variation in GDP in Malaysia is explained by other variables that are omitted in the model.

\section{$\mathrm{GDP}_{t}=1.6746-1.4830_{\text {POPU }}+0.0501_{\text {UNEM }}+0.3085_{\text {EXPT }}+\varepsilon_{t}$}

Turning to the main MLR regression, we found the coefficient of $B_{1} P O P U_{t}$ to be significant at $1 \%$ significant level suggesting Population significant effect on GDP. In this case, a $1 \%$ increase in Population caused the GDP to decrease by $-1.483 \%$ as the coefficient is negative in nature. Abdullah (2015) and Ahmad and Ahmed (2016) have documented the negative relationship and conclude that the increased rate of population can lead to rising unemployment rate. Subsequently, low income level that can cause gross domestic product to decline as people have no or less job. The result seems to be against the Malthus Theory of unemployment which among others states a positive or no significant relationship between population and the economic growth. Perhaps the increase in population must be accompanied by more job opportunities and a balanced job market to accommodate the increasing population growth or otherwise will result in greater unemployment rate.

Contrary to our expectation, the coefficient $B_{2} U N E M_{t}$ is not significant at $10 \%$ significance level, thus fail to reject the null hypothesis. Hence, Unemployment has no significant effect on GDP in Malaysia. The result is consistent with Mosikari (2013) and Ibrahim and Mahmoud (2016). These studies suggest that there may be other factors that affect GDP.

Finally, the coefficient $B_{3} E X P T_{t}$ reveals a positively significant value of 0.3085 at $99 \%$ level of confidence and thus rejecting the null hypothesis. The result provides evidence that a $1 \%$ increase in Export caused GDP in Malaysia to increase by $0.3085 \%$. This is in line with our expectation and the study of Senthosa (2002), Mudenda et. al, (2014) and Hamed et. al, (2014). Senthosa (2002) found that rising in export will create more job opportunities, thus increasing the economic growth in Botswana. Similarly, Mudenda et. al, (2014) and Hamed et. al, (2014) discovered that export diversification is positively related towards economic growth. Companies can diversify their product 
INTERNATIONAL JOURNAL OF ACADEMIC RESEARCH IN BUSINESS AND SOCIAL SCIENCES

Vol. 10, No. 3, March, 2020, E-ISSN: 2222-6990 C 2020 HRMARS

into international marketplace through international exports. Directly, income of the country will rise and subsequently boost the growth of an economy. The result augurs well with the Hecksher-Ohlin theory describing the modern approach to international trade. A country can only increase their economic growth by diversifying their export based on its comparative advantage. Hence, the result of this study fits the theory as it shows a positively related relationship between export and economic growth.

\section{Conclusion}

The present study tries to explore the relationship between selected macroeconomic variables namely population, unemployment and export toward economic growth in Malaysia. Overall, the study has managed to achieve the specified objective and research questions. From the Multiple Linear Regression estimation, we discover that Population to be significant and negatively related with the Malaysian economic growth. In line with our expectation, the result for export is significant and positively related with economic growth. Nevertheless, contrary to our expectation, unemployment, on the other hand is insignificant suggesting that GDP is not affected by the unemployment variable. The MLR estimation is adequately specified as supported by the diagnostic tests. The study contributes to the policy maker as they can use the significant variable, namely population and export to influence the positive effect of economic growth in Malaysia. For future study, we suggest a data extension to provide wider observation and using different techniques such as using the panel data. Further, to be more concrete, adding more variables such as interest rate, inflation and investment is also recommended.

\section{Corresponding Author}

Amirudin Mohd Nor

Faculty of Business and Management

Universiti Teknologi MARA, Melaka, Malaysia

Email: amirudinmohdnor@gmail.com

\section{References}

Abdullah, A., Shah, T., Sargani, G. R., Ali, A., \& Siraj, W. (2015). The effect of increase in population on the economic growth of Bangladesh. Developing Country Studies, 5(17), 87-94.

Afzal, M. (2009). Population growth and economic development in Pakistan. The Open Demography Journal, 2(1).

Ahmed, R. N., \& Ahmad, K. (2016). Impact of Population on Economic Growth: A Case Study of Pakistan. Bulletin of Business and Economics (BBE), 5(3), 162-176.

Ahmed, R. C., \& Ambreen, A. (2014), Economic Determinants of Unemployment in Pakistan: Cointegration Analysis. International Journal of Business and Social Science, 5(3), 209-221.

Alamro, H., \& Al-dalaien, Q. F. (2014). Modeling the Relationship between GDP and Unemployment for Okun's Law Specific to Jordan. Available at SSRN 2440674.

Albatel, A. H. (2005). Population growth and economic development in Saudi Arabia. Scientific Journal of King Faisal University (Humanities and Management Sciences), 6(2), 341-374. 
INTERNATIONAL JOURNAL OF ACADEMIC RESEARCH IN BUSINESS AND SOCIAL SCIENCES

Vol. 10, No. 3, March, 2020, E-ISSN: 2222-6990 @ 2020 HRMARS

Alhdiy, F. M., Johari, F., Daud, S. N. M., \& Rahman, A. A. (2015). Short and long term relationship between economic growth and unemployment in Egypt: An empirical analysis. Mediterranean Journal of Social Sciences, 6(4), 454.

Ali, Q., Shaikh, M., Shah, A. B., \& Shaikh, F. M. (2017). Relationship between Export and Economic Growth in Pakistan by Using OIS Technique. International Journal of Case Studies, 6, 4.

Ang. S. H., \& Loganathan, N. (2013). Interactions Between Economic Growth and Unemployment Condition in Asian Region. International Journal of Economics and Empirical Research, $1(12), 135-146$.

Furuoka, F. (2009). Population growth and economic development: New empirical evidence from Thailand. Economics Bulletin, 29(1), 1-14.

Furuoka, F., \& Munir, Q. (2010). Does export dependency hurt economic development? Empirical evidence from Singapore". Economics Bulletin, 30(1), 204-218.

Hamed, K., Hadi, D., \& Hossein, K. (2014). Export diversification and economic growth in some selected developing countries. African Journal of Business Management, 8(17), 700-704.

Hassan. M, Morteza. N., \& Hadi. D. (2013). Relationship Between Export Diversification and Economic Growth. International Journal of Basic Sciences \& Applied Research, 2 (12), 991-999.

Ibrahim. K., \& Mahmoud. A. (2016). Economic Growth and Unemployment Relationship: A Empirical Study for MENA Countries. International Journal of Managerial Studies and Research (IJMSR), $4(12), 19-24$.

Jorge Garza-Rodriguez and Cecilia I. Andrade-Velasco and Karen D. Martinez-Silva and Francisco D. Renteria-Rodriguez and Pedro A. Vallejo-Castillo, (2016) "The relationship between population growth and economic growth in Mexico", Economics Bulletin, 36(1), 97-107.

Meier, G. M., \& Rauch, J. E. (1995). Leading issues in economic development (Vol. 6). New York: Oxford University Press.

Michael, E. O., Emeka, A., \& Emmanuel, E. N. (2016). The Relationship between Unemployment and Economic Growth in Nigeria: Granger Causality Approach. Research Journal of Financial and Accounting, 7(24), 153-162.

Mosikari, T. J. (2013). The effect of unemployment rate on gross domestic product: Case of South Africa. Mediterranean Journal of Social Sciences, 4(6), 429.

Mudenda, C., Choga, I., \& Chigamba, C. (2014). The role of export diversification on economic growth in South Africa. Mediterranean Journal of Social Sciences, 5(9), 705.

Nam, C. B. (1994). Understanding Population Change. FE Peacock Publishers Inc.

Noor, Z. M., Nor, N. M., \& Ghani, J. (2007). The relationship between output and unemployment in Malaysia: Does Okun's law exist. International Journal of Economics and Management, 1(3), 337-344.

Obere, A., Thuku, G. K., \& Gachanja, P. (2013). The Impact of Population Change on Economic Growth in Kenya.

Özgür, M. I., \& Savaş, B (2009). Temporal Causality Between Population And Income In Turkey: An ARDL Bounds Testing Approach. Aksaray Üniversitesi İktisadi Ve İdari Bilimler, 1(1), 162-176.

Sentsho, J. (2000). Export revenues as determinants of economic growth: evidence from Botswana. University of Botswana, Gaborane, Botswana.

Shorbaji, M. (2009). Impact of economic growth on employment in the Egyptian economy. Magazine of North Africa Economies, (6), 141-170. 
INTERNATIONAL JOURNAL OF ACADEMIC RESEARCH IN BUSINESS AND SOCIAL SCIENCES

Vol. 10, No. 3, March, 2020, E-ISSN: 2222-6990 @ 2020 HRMARS

Tsen, W. H. (2007). Exports, Domestic Demand and Economic Growth: Some Empirical Evidence of The Middle East Countries. Journal of Economic Cooperation Among Islamic Countries, 28(2). 